http://dx.doi.org/10.12775/szhf.2018.024

RAFAє Michalski

Uniwersytet Miko€aja Kopernika, Toruń, Polska

E-MAIL: METASIS@UMK.PL

\title{
Chmury Arystofanesa w świetle Fenomenologii ducha. \\ Przyczynek do antropologicznej interpretacji fenomenu komizmu
}

\section{Uwagi wstępne}

Zaprezentowany artykuł ma z złożenia charakter szkicowy, stanowi próbę wykorzystania Heglowskiej analizy wczesnej komedii attyckiej z Fenomenologii ducha w interpretacji Chmur Arystofanesa. Wyznaczona przez niemieckiego filozofa perspektywa badawcza stanowić będzie punkt wyjścia dla rozważań antropologicznych, których celem jest wskazanie quasi-eidetycznych momentów zawartych w fenomenie komizmu oraz uzasadnienie tezy, że komedia kryje w sobie niewykorzystany potencjał filozoficzny. Literatura dotycząca twórczości dramatycznej Arystofanesa, filozofii Hegla i fenomenu komizmu w ogólności jest nieprzebrana. Nie ma tutaj miejsca, żeby wymienić nawet najważniejsze, przełomowe prace z zakresu trzech wspomnianych obszarów badawczych. W toku wywodów pojawią się odesłania jedynie do tych tekstów, na których bezpośrednio oparto główny zamysł artykułu. 
Zacznijmy od wskazania wątków i problemów związanych z analizowanym tematem, które pominąłem lub potraktowałem skrótowo, kierując się zasadą ekonomii myślenia i ograniczeniami ramowymi narzuconymi niniejszej publikacji. W moich rozważaniach rezygnuję z ,filologii” Arystofanesa (analiz krytycznoliterackich oraz szczegółowego omówienia przebiegu komedii) ${ }^{1}$, ponadto odstawiam na bok dręczące wielu historyków filozofii pytanie o „autentyczność” postaci Sokratesa ukazanej w tej komedii - nie będę roztrząsać, jak czynił to chociażby Kierkegaard, kwestii tego, jaki literacki obraz filozofa (Arystofanesa, Ksenofonta czy Platona) trafniej odzwierciedlił jego "rzeczywistą" osobowość. Do minimum zredukuję niezwykle istotny, polityczny charakter twórczości Arystofanesa ${ }^{2}$, a także problematykę genezy komedii jako gatunku dramatycznego ${ }^{3}$. Z kolei uwagi Hegla z Fenomenologii ducha dotyczące komedii zostaną potraktowane instrumentalnie w tym sensie, że znacznie ograniczę omówienie ich niezwykle złożonych i często niejednoznacznych powiązań z całością jego systemu filozoficznego. Ta zamierzona wybiórczość i skrótowość w wykorzystaniu literatury tematu ma ułatwić i przyspieszyć „przejście” do najważniejszej części wywodów, czyli próby antropologicznego ujęcia komizmu obecnego w Chmurach. Liczę, że zaproponowane przez mnie, antropologiczne spojrzenie na niepowtarzalne exemplum, jakim jest ta komedia, pozwoli mi wyprowadzić wnioski o charakterze bardziej ogólnym, niż można byłoby się spodziewać po interpretacji utworu obarczonego złą sławą wulgarności i niewyszukanej parodystyki.

W pierwszym kroku chciałbym przejąć od Hegla intuicję, że komedia stanowi zwieńczenie „religii sztuki” i przewyższa - pod względem stopnia samowiedzy ducha i rozwoju wolności - tragedię. Tak właśnie odczytuje rolę komedii w Fenomenologii ducha Niklas Hebing w swojej rozprawie Hegels Ästhetik des Komischen ${ }^{4}$, która pomogła mi zrozumieć hermetyczne spekulacje niemieckiego filozofa. Wychodząc z tego założenia, spróbuję pokusić się o przedstawienie kilku roboczych tez dotyczących komizmu jako fundamentalnego fenomenu ludzkiej kondycji, który niezależnie od swoich historycznych i kulturowych metamorfoz, odsłania pewne uniwersalne, niezmienne własności. Przy tym skoncentruję się na wskazaniu tych elementów, które

${ }^{1}$ Por. pierwsze w Polsce, kompleksowe, historyczno-literackie omówienie dzieł Arystofanesa z odnośnikami bibliograficznymi: O. Śmiechowicz, Arystofanes, Warszawa 2015.

${ }^{2}$ N. W. Slater, Spectator Politics: Metatheater and Performance in Aristophanes, Philadelphia 2002; D. Konstan, Greek Comedy and Ideology, New York 1995.

${ }^{3}$ F. M. Cornford, The Origin of Attic Comedy, Gloucester 1968.

${ }^{4}$ N. Hebing, Hegels Ästhetik des Komischen, Hamburg 2015, s. 77-120, zwłaszcza s. 110. 
wykraczają poza obiegowe i utrwalone w tradycji filozoficznej wyobrażenia o komedii jako formie sztuki służącej rozładowaniu społecznych i psychicznych napięć, kompensującej stresogenne doświadczenie codzienności, obnażającej wady i ułomności ludzkich zachowań, politycznej gry o władzę, instytucjonalnych zakazów, odsłaniającej stabuizowane sfery życia etc. Nie zaprzeczam, że komedia pełni również takie funkcje, ale chciałbym pokazać, że ponadto wyzwala ona, a przynajmniej sugeruje pewien rodzaj uniwersalnego doświadczenia, z którego da się wyprowadzić daleko idące implikacje filozoficzne. Celem artykułu jest więc uzasadnienie tezy, że komedia stanowi swoiste, niedoceniane dotąd przedpole filozofii, z którego być może dałoby się wyprowadzić posttragiczny obraz człowieka, odmienny od tego, jaki proponuje szkoła lacanowska, ironizm Rorty’ego, czy kynizm Sloterdijka, by wymienić sztandarowe przykłady współczesnych filozofów próbujących przekroczyć paradygmat tragicznego ujmowania conditio humana w stronę „komicznej” wizji człowieka. Idąc śladem znakomitych analiz Agaty Bielik-Robson zawartych w książce Erros. Mesjański witalizm i filozofia ${ }^{5}$, przyjmuję (choć w kontrze do jej sceptycznej postawy wobec komedii), że „doświadczenie komiczne" odsłania obraz życia jako swoistego dla homo sapiens ekscesu witalnego będącego skutkiem wybujałości nieskanalizowanej i nieukierunkowanej energii popędowej. W komediowej odsłonie życie byłoby zatem czymś więcej niż biologicznym procesem podporządkowanym imperatywowi przetrwania. Wprawdzie wyrasta ono i rozgrywa się w przestrzeni naturalnej witalności, ale jednocześnie przekracza ją w stronę nowych niezrealizowanych możliwości wyzwolonych przez duchową sublimację, która stawia opór zarówno myśleniu absolutyzującemu śmierć, jak i związanemu z nim fatalizmowi. Za Bielik-Robson roboczo nazwę je Errosem, czyli życiem, które stawia na szczęśliwy błąd, na zbawienne odchylenie od kierunku rozwoju narzuconego przez determinizm trwania biologicznego. Jak pisze filozofka, Erros to „[...] nieskończone pragnienie życia [...], które samo postrzega siebie jako szczęsną anomalię, wyjątek śmiało przeciwstawiony regule, pomyłkę urastającą do rangi nowej zasady i przekuwającą się w nowy rodzaj bytu"'. Podążając za tą intuicją, chciałbym pokazać, że komedia odsłania ekscesywny wymiar „errotycznego" życia kryjący w sobie nieurzeczywistniony potencjał znaczenia i działania, któremu towarzyszy stan autoafektacji samoutwierdzającej się podmiotowości.

\footnotetext{
${ }^{5}$ A. Bielik-Robson, Erros. Mesjański witalizm i filozofia, Kraków 2012.

${ }^{6}$ A. Bielik-Robson, „Na pustyni”. Kryptoteologie późnej nowoczesności, Kraków 2008, s. 39.
} 
Jak podkreśla Hegel, komedia doprowadza do końca proces uwalniania się subiektywności od fatum, od abstrakcyjnej ogólności, którą za czasów Arystofanesa uosabiał świat olimpijskich bogów z zasadą ananke na czele. To w niej właśnie podmiot w pełni uświadamia sobie swoją wolność, niezawisłość od transcendentnych mocy i abstrakcyjnych zasad. Dla Hegla wraz z komedią kończy się sztuka, a płonąca myślarnia (phronisterion) Sokratesa z zakończenia Chmur symbolizuje "pożar” wyobrażeniowego świata duchowego Innobytu. Płomienie trawią fałszywe idee i zwodnicze fantazmaty, pozostaje jedynie pustka, w której podmiot odczuwa takie zadowolenie, „,[...] jakiego nigdzie poza tą komedią już znaleźć nie można"7.

Siła dialektycznego napędu Fenomenologii ducha każe Heglowi przeskoczyć po rozdziale poświęconym komedii do „erotycznego”, tzn. dążącego do pojednania chrześcijaństwa. Trop komiczny urywa się. Czy oznacza to jednak, że komedia to tylko - i aż - pewna faza rozwoju ducha, którą należy przekroczyć, gdyż w przeciwnym razie duch utknie w ślepym zaułku, pozbawiony aksjologicznych drogowskazów i narzędzi poznawczych? Hegel nie odpowiada na to pytanie, nawet go nie stawia.

Krótki fragment poświęcony komedii z Fenomenologii ducha pozostawał przez długi czas ślepą plamką w obszernej egzegezie jego filozofii ${ }^{8}$. Za przełomową pracę, która dostrzegła znaczenie komizmu w całej filozofii Hegla możemy niewątpliwie uznać wspomnianą już książkę Niklasa Hebinga Hegels Ästhetik des Komischen, na której będzie bazowała rekonstrukcja Heglowskiej wykładni komedii zawarta w pierwszej części artykułu․ W tym miejscu chciałbym podkreślić, że rekonstrukcja ta wraz z jej najważniejszą, odbiegającą od standardowych interpretacji tezą o prymacie komiczności nad tragicznością może wywołać opór wśród heglowskich egzegetów. Broniąc się przed ewentualnymi zarzutami o „błędną" wykładnię tego dzieła, mogę tylko stwierdzić, że moim celem nie było wierne objaśnianie myśli niemieckiego filozofa, lecz poszukiwanie inspiracji, które mogą pomóc odsłonić głębszy wymiar badanego zjawiska. Fenomenologia ducha zawiera niejasne ze względu na brak precyzyjnych definicji używanych w niej pojęć oraz wysoce abstrakcyjne wywody, które zawsze budziły kontrowersje interpretacyjne, dlatego

${ }^{7}$ G.W. F. Hegel, Fenomenologia ducha, t. 2, przeł. A. Landman, Warszawa 2010, s. 286.

${ }^{8}$ Do wyjątków należą między innymi prace: M. Schulte, "Tragödie im Sittlichen”. Zur Dramentheorie Hegels, München 1992; W. Hamacher, Das Ende der Kunst mit der Maske, [w:] Sprachen der Ironie - Sprachen des Ernstes, hg. K. H. Bohrer, Frankfurt am Main 2000, s. 121155; S. Kraft, Zum Ende der Komödie. Eine Theoriegeschichte des Happyends, Göttingen 2011.

${ }^{9}$ N. Hebing, Hegels Ästhetik des Komischen, Hamburg 2015, s. 77-120. 
każde odczytanie niezgodne z kanoniczną wykładnią (jeśli zgodzimy się, że taka w ogóle istnieje) będzie obarczone ryzykiem nadinterpretacji. Zainteresowanych bardziej szczegółowym uzasadnieniem zaproponowanej wykładni w kontekście całej filozofii Hegla odsyłam do opracowania Hebinga. Przedstawiona przeze mnie $\mathrm{w}$ tym artykule interpretacja nie zatrzyma się jednak, jak już wspomniałem, w granicach wyznaczonych przez idee wyinterpretowane z filozofii Hegla.

Uznaję jej wartość poznawczą, korzystam z jej osiągnięć, ale tylko po to, aby w następnym kroku przejść do skonstruowania hipotez o charakterze antropologicznym, opuszczając tym samym obszar dziejowej odysei ducha w postaci, jaką opisał Hegel. Nie oznacza to jednak, że rezygnuję całkowicie $\mathrm{z}$ namysłu historiozoficznego ${ }^{10}$. Ten będzie stale obecny w tle wszystkich wywodów, ustępując miejsca perspektywie antropologicznej.

Odo Marquard zaproponował określenie antropologii filozoficznej jako refleksji przeciwstawiającej się filozofii dziejów i metafizyce, a wychodzącej z obszaru codziennego doświadczenia, z wymiaru tak zwanego Lebensweltu $^{11}$. Według autora Schwierigkeiten mit der Geschichtsphilosophie antropologia szuka człowieczeństwa przede wszystkim w naturze - jakkolwiek rozumianej, choć jednocześnie nie traci z oczu jego uwikłania w proces dziejowych i kulturowych przekształceń. Właśnie tak pojętą perspektywę antropologiczną chciałbym zastosować w zaprezentowanym artykule, szkicując kilka roboczych hipotez, które być może przyczynią się do filozoficznej rehabilitacji komedii i uznania komizmu za istotną kategorię pozwalającą lepiej zrozumieć przygodę zwaną człowiekiem.

Śmiech, jak pisał Plessner, stanowi skrajną reakcję na sytuacje graniczne i nie da się go wywieść z natury człowieka, ponieważ wyznacza on jej nieprzekraczalne granice ${ }^{12}$. Istnieje nieprzebrana ilość przejawów i sposobów wywoływania śmiechu - zarówno potocznych, całkiem spontanicznych, jak i tych, które podlegają określonym estetycznym rygorom. Można długo dyskutować nad tym, czym jest sama komedia i śmiech, jednakże w tej niekończącej się debacie pewna pozostaje jedna myśl: w komedii chodzi o śmiech.

\footnotetext{
${ }^{10}$ Należy przy tym pamiętać, że „historiozoficzna” perspektywa Fenomenologii Ducha nie ma znaczenia chronologicznego, temporalnego, lecz dotyczy ukrytej, „pozaczasowej” logiki rozwoju ducha.

${ }^{11}$ O. Marquard, Schwierigkeiten mit der Geschichtsphilosophie, Frankfurt am Main 1973.

${ }^{12} \mathrm{H}$. Plessner, Śmiech i płacz. Badania nad granicami ludzkiego zachowania, przeł. A. Zwolińska, Z. Nerczuk, Kęty 2004.
} 
Zamiast wikłać się w beznadziejne spory pojęciowe, sięgnijmy na wstępie po interesującą intuicję, jaką może obudzić triada bogów czczona w starożytnej Sparcie, do której zaliczał się bóg śmiechu (gr. gelos), lęku (phobos) i śmierci (thanatos $)^{13}$. Zapewne nigdy nie dowiemy się, jakie przyczyny legły u podłoża takiej konstelacji boskich epifanii. Jednak zestawienie to nasuwa przypuszczenie, że mamy tutaj do czynienia z jakimś głębokim powiązaniem trzech kluczowych dla ludzkiej kondycji stanów emocjonalnych. Namacalny związek śmiechu z lękiem, a zwłaszcza z lękiem przed śmiercią znajdziemy w obfitej literaturze opisującej reakcje ludzi, którym udało się umknąć przed śmiertelnym zagrożeniem - śmiech działa tutaj jak środek katarktyczny, rozładowuje napięcie, przywraca równowagę.

Czy możemy rozszerzyć tę obserwację na inne rodzaje śmiechu? Czy każdy rodzaj śmiechu jest podszyty jakąś rudymentarną postacią lęku i w paradoksalny sposób zapowiada nieuchronne doświadczenie śmierci?

Jeśli poważnie potraktujemy obraz świata i ludzi przedstawiony w komicznej deformacji, będziemy musieli przyznać, że ukazuje on w istocie rzeczywistość w stanie rozpadu: ludzkie uniwersum tuż przed nadchodzącą katastrofą ${ }^{14}$. Korowód szaleńców, ludzi opętanych chroniczną głupotą, złośliwe teściowie, niewierni mężowie, skorumpowani politycy, parodystyczna degradacja uznanych wartości, prymitywny, patologiczny erotyzm, skatologia, zbrodnie, urzeczowienie - wielorakie stabuizowane bądź całkowicie wyparte $\mathrm{z}$ oficjalnego porządku pokłady treści tworzą nieskończenie zmienny, kalejdoskopowy obraz świata, który utracił stałe fundamenty i nieuchronne zmierza do agonalnego chaosu. Śmiech rozbrzmiewa w tej perspektywie jak sygnał alarmowy, jak ostrzeżenie przed końcem świata, jaki znamy. Śmiech może stać się narzędziem zniszczenia. Ta właśnie obawa skłoniła Platona do wyeliminowania komedii z projektu idealnego państwa. Śmiech degraduje i upokarza zarówno wynaturzenia ludzkiej natury: nikczemność, głupotę, małostkowość etc. - taką funkcję gelos Platon mógłby jeszcze zaakceptować, ale również to, co szlachetne i wartościowe. Ta ambiwalencja, a wręcz irracjonalność śmiechu, jego neutralność względem dobra i zła stanowi poważne

\footnotetext{
${ }^{13}$ Boga Gelosa wspomina Filostrat Starszy w swoim opisie obrazu Andryjczyków w: Filostrat Starszy, Obrazy, przeł. R. Popowski, Warszawa 2004, s. 169. Więcej na ten temat: L. Prütting, Homo ridens, t. 1, München 2013, s. 163-164.

${ }^{14}$ J. Ritter, Über das Lachen, [w:] tenże, Subjektivität. Sechs Aufsätze, Frankfurt am Main 1974, s. 61 .
} 
zagrożenie dla ustroju, w którym ma rządzić rozum oświetlony blaskiem prawdziwego poznania ${ }^{15}$.

Arystofanes nie znał filozofii platońskiej i prawdopodobnie nie roztrząsał zagadkowego sensu spartiańskiej triady bóstw, jednak dla naszych wywodów nie ma to istotnego znaczenia. Idąc tropem wskazanej intuicji, przyjmujemy, że śmiech łączy się na głębszym emocjonalnym poziomie z lękiem - ostatecznie z lękiem przed śmiercią. Gelos może chronić przed traumą tanatycznego doświadczenia na dwa sposoby: albo przez neutralizację trwogi, przez rozładowanie napięcia, które prowadzi do pogodzenia się z nieuchronnością końca życia, a ostatecznie do pokornej apologii absolutnego „Pana śmierci” i afirmatywnego podporządkowania się ślepej potędze konieczności, albo przez rebeliancki opór wobec bezwzględnej władzy przeznaczenia, który otwiera przed człowiekiem nowe możliwości i prowadzi do afirmacji życia jako tymczasowej, ale nabrzmiałej sensem i radością creatio continua.

Wydaje się, że Hegel dostrzegł w Arystofanesowej komedii tę właśnie buntowniczą postawę człowieka wobec mortis, dlatego wyniósł ją ponad doświadczenie tragiczne, które wieńczy kapitulacja podmiotowości przed wszechwładnym fatum. Przyjrzyjmy się zatem Heglowskiej refleksji nad komedią.

\section{Heglowska interpretacja wczesnej komedii attyckiej}

Aby przybliżyć się do zrozumienia filozoficznego przesłania Chmur Arystofanesa, sięgniemy do koncepcji komedii, jaką zaproponował Hegel w swojej Fenomenologii ducha. Twórczość Arystofanesa stanowi dla niemieckiego filozofa nie tylko kulminacyjny punkt rozwoju attyckiej komedii ${ }^{16}$, ale ponadto symptom końca sztuki antycznej w ogólności. Co ciekawe, opisując

${ }^{15}$ R. Michalski, Rozważania wokół koncepcji śmiechu Platona, „Studia z Historii Filozofii”, t. 6, 2015, z. 4, s. 149-174.

${ }^{16}$ Hegel nie odnosi się w Fenomenologii ducha explicte do wczesnej komedii attyckiej, ale na podstawie wywodów na temat komizmu zawartych choćby w późniejszych Wykładach o estetyce oraz często wyrażanej wysokiej ocenie twórczości Arystofanesa i krytyce Eurypidesa można przyjąć założenie, że zwieńczeniem tego gatunku są dla Hegla utwory zaliczane do wczesnej komedii attyckiej, po której zachowały się w całości jedynie dzieła Arystofanesa. Tak również argumentuje w swojej rozprawie Hebing. Por. N. Hebing, Hegels Ästhetik des Komischen ..., s. 77-120. 
kolejne fazy rozwoju samowiedzy ducha, Hegel umieszcza ją na etapie, który następuje po tragedii, a zatem, jak przekonuje Hebing, wyraźnie przypisuje większą filozoficzną wartość komicznemu absurdowi aniżeli tragizmowi. Temat komedii pojawia się w części poświęconej religii, a ściślej religii sztuki, którą poprzedza religia naturalna, a po której następuje religia jawna. Wraz z religią duch przestaje być wyłącznie obiektem wiedzy i niejako sam uzyskuje samoświadomość.

W rozpatrywanych przez nas dotychczas ukształtowaniach, które ogólnie biorąc różniły się od siebie jako świadomość, samowiedza, rozum i duch, mieliśmy wprawdzie do czynienia również z religią jako świadomością istoty absolutnej w ogóle, ale tylko z punktu widzenia świadomości, uświadamiającej sobie istotę absolutną. Nie występowała natomiast $\mathrm{w}$ tych formach istota absolutna sama w sobie i dla siebie - nie występowała samowiedza ducha ${ }^{17}$.

Innymi słowy, na etapie religii duch staje się duchem świadomym siebie, staje się przedmiotem samego siebie ${ }^{18}$. Należy przy tym pamiętać, że wprawdzie często opisuje się ducha jako wszechobejmujący wyraz podmiotowości, to jednak określenie to ma charakter alegoryczny. Jak pisze Żelazny:

$\mathrm{W}$ istocie bowiem, jakkolwiek ducha tworzą jednostkowe podmioty, sam duch nie jest podmiotem w tym sensie, w jakim podmiotem jest ludzka jednostka. Nie ma on mianowicie swej jaźni, jeśli przez to słowo rozumieć samoświadomość. Jest składnicą wszystkich prawd i wszystkich treści, ale samoświadomość tych prawd i tych treści osiąga dopiero poprzez człowieka ${ }^{19}$.

Można więc powiedzieć, że w heglowskiej odysei ducha chodzi zdecydowanie o coś więcej niż o jednostkę, ale ostatecznie to właśnie ona okazuje się głównym bohaterem najważniejszych perypetii dialektycznej podróży, w której komedia odgrywa niebagatelną rolę.

Hegel omawia komedię w rozdziale traktującym o „religii sztuki”. W największym skrócie „religia sztuki” obejmuje rozmaite poszukiwania mające na celu znalezienie coraz trafniejszego wyrazu dla boskości. Architektura, rzeźba, kult, misteria i poezja starożytnej Grecji stanowią w istocie próbę ukazania boskości w formie zmysłowej naoczności, dlatego ten rodzaj religii

\footnotetext{
${ }^{17}$ G. W. F. Hegel, Fenomenologia ducha ..., s. 281.

18 Tamże, s. 282.

${ }^{19}$ M. Żelazny, Heglowska filozofia ducha, Toruń 2000, s. 83.
} 
ma dla filozofa charakter stricte estetyczny. Prezentacja ducha w estetycznej formie religii sztuki nie dokonuje się jednak w prosty sposób, lecz przyjmuje charakter procesu, w którym duch poszukuje właściwego dla siebie wyrazu: najpierw w abstrakcyjnym dziele sztuki (w posągach bogów, hymnach, kulcie), potem w żywym dziele sztuki (w misteriach) i wreszcie w duchowym dziele sztuki, którego medium jest język - duch ujawnia się tutaj w formie eposu, tragedii i komedii. Wszystkie trzy wymienione gatunki przedstawiają relację między jednostkowością a ogólnością, między człowiekiem a Bogiem, a następnie stopniowo podają w wątpliwość tę relację i dążą, każdy na swój sposób, do pojednania, w którym boskość nie może być już określana jako to, co Inne i zewnętrzne ${ }^{20}$. Pomiędzy biegunami ogólności i jednostkowości lokuje się w tych gatunkach to, co szczegółowe, czyli epicki, tragiczny i komiczny bohater. Wszystkie trzy gatunki ukazują ponadto proces kształtowania się naturalnej etyczności, czyli systemu norm, wartości, instytucji, konwencji i zwyczajów organizujących zbiorowe życie wspólnoty, a także sposób, w jaki jednostka próbuje umiejscowić się w tym systemie. Jak pisze Hebing: „Na podstawie historii antycznych gatunków Hegel kreśli drogę, która zaczyna się od bezpośredniej korespondencji między indywiduum a wspólnotą, podmiotem a substancją, na której jednak wolna samoświadomość traci swoje naturalne zaufanie i popada w rozpacz, ponieważ jej jaźń nie rozpoznaje wolności w sferze etycznej, a która na swoim końcu prowadzi do zburzenia pięknej etyczności za cenę realizacji indywidualności jednostkowego, wolnego człowieka"21.

Epos odzwierciedla stan harmonii między bezrefleksyjną jednostką a wspólnotą czy, jak pisze Hegel, między podmiotem a substancją, tragedia uwypukla konflikt między nimi, ukazuje uwalniającą się samoświadomość, która traci swoje zaufanie do panującego porządku, a wreszcie komedia prowadzi do zniszczenia harmonii „pięknej etyczności”22.

Rezultatem tej destrukcji, która zarazem oznacza koniec sztuki (rozumianej jako forma przedstawiania boskości) są narodziny samoświadomej, wolnej od więzów Sittlichkeit podmiotowości. Oczywiście komedia nie oznacza dla Hegla końca odysei ducha, jej kolejnym etapem jest bowiem religia jawna (chrześcijaństwo) oraz wiedza absolutna. Nie mniej jednak rozdział o kome-

\footnotetext{
${ }^{20}$ Por. N. Hebing, Hegels Ästhetik..., s. 79.

${ }^{21}$ Tamże, s. 79.

22 Por. K. Guczalska, Państwo jako dzieło sztuki. Piękno i wolność w filozofii Hegla, Kraków 2010.
} 
dii, mimo skromnych rozmiarów, wydaje się mieć kluczowe znaczenie dla całej konstrukcji filozoficznej Hegla. Spróbujmy teraz dokładniej przyjrzeć się jego rozważaniom na ten temat. W tym celu będziemy musieli pokrótce omówić dwa poprzedzające komedię (w wymiarze logicznym) gatunki eposu i tragedii.

Naszą rekonstrukcję zacznijmy od kilku ogólnych uwag dotyczących tego, jak Hegel opisuje „duchową kondycję” świata antycznej Grecji. Jego podstawową tezą jest tutaj stwierdzenie, że na etapie „religii sztuki” duch urzeczywistnił się jako duch etyczny, w którym formy świadomości stają się formami świata ${ }^{23}$, stają się zatem obiektywnym porządkiem, który zyskuje niezależność od aktorów społecznych. Obywatele, polites, wyobrażają sobie ducha w postaci rozmaitych relacji do świata bogów. Substancja ducha rozpada się na społeczne normy, niepisane reguły, zwyczaje, na zróżnicowane formy życia we wspólnocie, które stały się czymś oczywistym i bezdyskusyjnym. Prawomocność wszystkich norm, które tworzą etyczne uniwersum wspólnoty opiera się na bezwiednie przyswojonych wyobrażeniach mitologicznych. To właśnie mitologiczna wyobraźnia legitymizuje panujący porządek zwyczajów i wartości.

$\mathrm{W}$ eposie mamy do czynienia $\mathrm{z}$ imaginarium wykreowanym przez mowę pieśniarza, która ukazuje istotną jedność świata bogów i ludzi „[...] pod postacią przyjaznych stosunków zewnętrznych między tymi dwoma światami”24. W epickim przedstawieniu nie liczy się jaźń samego pieśniarza, „[...] lecz jego muza, ogólna pieśń" ${ }^{25}$, której bohaterzy ucieleśniają naród. Absolutem epickiego uniwersum jest panteon bogów olimpijskich, którzy jednak noszą wyraźne ślady ludzkich cech i nie mogą uchodzić za prawdziwą zasadę absolutu, ponieważ partycypują w sferze skończonej jednostkowości. $\mathrm{W}$ obrębie tej jednostkowości podejmują oni wprawdzie pewne działania, kooperują lub rywalizują z ludźmi, ale z tego właśnie powodu nie mogą podtrzymać wyobrażenia wiecznej boskości. „Toteż powaga mocy ogólnych jest tu jakimś śmiesznym, niepotrzebnym nadmiarem, gdyż naprawdę są one siłami działających jednostek; równie niepotrzebne są wysiłki i praca jednostek, gdyż moce ogólne same raczej wszystkim kierują"26. Hegel opisuje zatem świat eposu jako rodzaj sakralnej groteski, w której śmiertelni ludzie potrafią

\footnotetext{
${ }^{23}$ Por. N. Hebing, Hegels Ästhetik..., s. 80.

${ }^{24}$ G.W.F. Hegel, Fenomenologia ducha..., s. 269.

25 Tamże, s. 270.

${ }^{26}$ Tamże, s. 271.
} 
podporządkować sobie bogów, obrażać ich, a zarazem nieśmiertelni bogowie nadają ostateczny sens wszystkim zdarzeniom. Śmieszność uwidocznia się zwłaszcza w relacjach między samymi bogami, którzy choć są nieprzemijalnymi istotami, toczą między sobą przypadkowe, „ludzkie” spory. Hegel stwierdza: „Cel działania i samo działanie, ponieważ zwraca się przeciwko „innemu”, i tym samym przeciw niezwyciężonej sile boskiej, jest jakąś przypadkową, pustą brawurą, która tak samo się rozpływa, przemieniając pozorną powagę działania w zupełnie bezpieczną, pewną samej siebie grę bez rezultatów i wyników”27. Filozof pisząc, że konflikt między bogami jest „jakimś komicznym zapomnieniem o swej wiecznej naturze"28, zdaje się sugerować, iż greccy bogowie obarczeni są piętnem śmieszności, a być może nawet sami śmieją się z siebie, jak Zeus w 21 księdze Iliady (w. 250-256): „Ale między bogami nowa kłótnia wzrosła / I zawziętych nienawiść na dwie strony niosła / Lecą na siebie, w ręku z groźnymi oszczepy. / Ryknęła ziemia, nieba zatrzęsły się sklepy. / Obaczywszy z Olimpu Zeus, co się dzieje, / Patrzy na walkę bogów, a w sercu się śmieje”. Aby zakamuflować sprzeczność zawartą w takim skazanym na groteskę wyobrażeniu bogów oraz nadać jedność światu przedstawionemu, epos odwołuje się do instancji, która podtrzymuje autorytet boskości - jest nią anake, los jako "pozbawiona pojęcia pustka konieczności”29, której podlegają zarówno bogowie, jak i ludzie.

Hegla interesuje proces rozwoju ludzkiej samowiedzy i wolności. Epos odzwierciedla, jego zdaniem, harmonijne uniwersum, w którym bogowie olimpijscy komunikują się z światem ludzkim. Tę wykładnię potwierdzają analizy Bruno Snella, który dowodzi, że epicki bohater nie odczuwa siebie jako autonomicznego podmiotu, niezależnego centrum kierującego swoją wolą i decyzjami, lecz jako pole działania samowolnych sił, które zawiadują jego poczynaniami z zewnątrz ${ }^{30}$. Nie oznacza to jednak, że czuje się on zależny od bogów olimpijskich. Ich interwencje nie budzą w nim trwogi, ponieważ należą do naturalnego porządku świata. W epickim uniwersum panuje zatem stan pojednania obydwu wymiarów rzeczywistości, którego nie zakłócają okazjonalne interwencje bogów, nie mające nic wspólnego z cudownością w znaczeniu chwilowego zawieszenia praw natury ${ }^{31}$.

\footnotetext{
${ }^{27}$ Tamże, s. 272.

${ }^{28}$ Tamże.

${ }^{29}$ G. W. F. Hegel, Fenomenologia ducha, s. 273.

${ }^{30}$ B. Snell, Odkrycie ducha. Studia o greckich korzeniach europejskiego myślenia, przeł.

A. Onsymow, Warszawa 2009.

${ }^{31}$ Tamże, s. 41-59.
} 
Zamkniętość epickiego świata rozpada się w tragedii na dwie równorzędne siły, które popadają we wzajemny prawny konflikt - w języku Hegla, konflikt między jednostkowością a ogólnością ${ }^{32}$. W eposie jednostkowość reprezentował wycofany z przedstawienia pieśniarz, który jedynie przekazywał poprzez mowę treść utworu, natomiast $\mathrm{w}$ tragedii jednostkowość reprezentuje tragiczny bohater, który przesuwa się do centrum akcji, do wnętrza świata przedstawionego. Wraz z tym przesunięciem z działań narodu (ucieleśnionego w bohaterach eposu) do działań jednostki (bohatera tragicznego) następuje zmiana formy przedstawienia treści. Pieśniarz epicki tylko przekazywał ogólne treści w formie narracji trzecioosobowej, natomiast treść wyrażona przez tragicznego pieśniarza staje się konkretną mową i działaniem samego bohatera. Innymi słowy, język przestaje być w tragedii ogólnym medium reprezentacji, lecz indywidualizuje się, przechodzi w treść - jak pisze Hegel. Słowa i czyny bohaterów tragicznych wyrażają ich zamiary, obawy i pragnienia, potwierdzają zatem ich samoświadomość. Oczywiście również w tragedii pojawia się moment reprezentacji, pośredniego przedstawienia, ale służy on uwypukleniu jednostkowości i suwerenności bohaterów. „Bohater jest tym, kto mówi, a przedstawienie pokazuje słuchaczowi, będącemu zarazem widzem, świadomych siebie ludzi, którzy znają swe prawa i swój cel, potęgę i wolę swej określoności" ${ }^{33}$. Tragedia pokazuje zarazem, że niezależność jednostki ma swoje granice, jest ograniczona przez prawa, które można uznać za pozostałość po epickim świecie bogów.

Substancja boskości dzieli się w świecie tragicznym na dwie etyczne siły: nadziemne królestwo praw ludzkich (prawo państwowe, solidarność z narodem) i podziemne prawo boskie (rodzina, wspólnota krwi), które na poziomie boskości są równoważne, ale w świecie skończonym jawią się jako dwie antagonistyczne zasady. Hegel przytacza przykład Antygony Sofoklesa, gdzie tytułowa bohaterka popada w konflikt z królem Kreonem wynikający z jednostronności postaw, jakie przyjmują wobec siebie. Antygona nie rozpoznaje tego, że Kreon urzeczywistnia ludzkie prawo, lecz jego decyzję uznaje za gwałt i niesprawiedliwość, natomiast Kreon dostrzega w jej postępowaniu akt rebelii i nieposłuszeństwa. Oboje ponoszą karę: Antygona ginie, Kreon traci wszystkich najbliższych, ponieważ zbyt późno rozpoznali swoją winę (hamartia). Instancją rozstrzygającą spór jest tutaj negatywna moc losu, która usuwa winę płynącą z roszczeń odwołujących do odmiennych porząd-

\footnotetext{
${ }^{32}$ Por. N. Hebing, Hegels Ästhetik..., s. 86.

${ }^{33}$ G. W. F. Hegel, Fenomenologia ducha, s. 274.
} 
ków prawa skonfliktowanych na poziomie ludzkiego świata, a równoważnych w perspektywie boskiej. Tragiczny konflikt zostaje zatem zniesiony i pojednany dopiero dzięki śmierci głównego bohatera. Zagłada indywidualności ratuje etyczny świat. W rezultacie tragicznego przywrócenia etyczności upadają nie tylko konkurujące ze sobą moce, ale również grecki politeizm, który nie był w stanie pojednać substancji (prawa) i rzeczywistości. W eposie antropormorficznie przedstawiani bogowie okazali się bezsilni, a przez to okryci aurą śmieszności. W tragedii natomiast zaczyna się „[r] ugowanie pozbawionych istoty wyobrażeń [bogów], które było postulatem filozofii greckiej”34.

Hegel podkreśla, że tragiczne pojednanie nie jest wolne od rozdwojenia. Bohater rozpada się bowiem na personę (maskę) i swoją rzeczywistą jaźń. Maska ucieleśnia jeden z charakterów boskiej substancji, etyczną moc działającą jako naczelna zasada, za którą powinien podążać bohater. Jego jaźń musi podporządkować się nieświadomej masce, dlatego ostatecznie nie rozpoznaje w swoim działaniu wpływu boskości, lecz postrzega ją jako coś obcego, zewnętrznego $^{35}$. W tym sensie tragicznemu podmiotowi brakuje pełnej samoświadomości, to znaczy, doświadczenia własnej tożsamości w jedności $\mathrm{z}$ absolutem. Absolut jawi się tragicznemu bohaterowi jako boski los, jako przeciwstawna mu abstrakcyjna siła, której musi ulec. Nie jest więc pełnym człowiekiem, lecz niejako znika za skrywającą jego twarz maską. Dopiero w dalszym procesie rozwoju ducha na etapie "religii sztuki”, czyli w komedii, spod maski wyłania się podmiot i osiąga urzeczywistnienie swej jaźni jako samoświadomości ${ }^{36}$. W komicznej grze demaskuje on wyobrażenia bogów jako swoje własne projekcje i dzięki negatywnej sile deziluzji rozpoznaje samo siebie jako boskość. Jak pisze Hebing: „W przejściu z tragedii do komedii człowiek staje się bogiem - a jednak pozostaje zarazem całym człowiekiem"37.

Według Hegla komedia odzwierciedla końcową fazę istnienia świata greckiego. Jej początkiem jest stan, który wieńczy tragedię, ale pozbawiony jest śmiertelnej powagi agonalnego konfliktu. Bohater komiczny nie pada już ofiarą etyczności ani losu, lecz potrafi wznieść się ponad narzucone mu zewnętrzne moce, nie poświęca już siebie, lecz ratuje swoją indywidualność i wyraża pogodną akceptację życia. Zarówno chór, jak i widownia nie muszą

\footnotetext{
${ }^{34}$ Tamże, s. 280-281.

${ }^{35}$ Por. N. Hebing, Hegels Ästhetik..., s. 91.

${ }^{36}$ Por. tamże.

37 Tamże, s. 92.
} 
już reagować na przedstawienie współczuciem, nie odczuwają grozy ani lęku przed bogami i bezlitosną koniecznością losu. W tym sensie nie różnią się od heroicznych, nieustraszonych bohaterów tragedii, ponieważ zostają radośnie uwolnieni w samoświadomym śmiechu i przyłączają się do pewnej siebie, suwerennie działającej podmiotowości komicznej. Owa komiczna świadomość nie musi rozgrywać żadnego etycznego konfliktu ani ulegać władzy opatrzności. Hegel pokazuje, że w ramach tej świadomości proces oświecenia zachodzi dokładnie tym momencie, gdy rozpoznaje ona iluzoryczność maski noszonej na scenie. Maska ta staje się dla komicznego bohatera jednostronnym atrybutem, który może on w każdej chwili odrzucić.

Rzeczywista jaźń (podmiot) czuje się przeto wyższa ponad tego rodzaju moment jako ponad coś, co jest jednostkową cechą i - nałożywszy maskę tej jednostkowej cechy - mówi z ironią o niej, która chciałaby być czymś dla siebie. Pretensjonalność istotności ogólnej zostaje zdradzona jaźni; istotność ta zostaje wplątana w jakąś rzeczywistość i maska spada z niej właśnie w tej chwili, w której chce ona być czymś dorzecznym. Jaźń, która występuje tu w swym znaczeniu czegoś rzeczywistego, gra tę istotność ogólną w masce, którą już raz na siebie nałożyła, aby być jej osobą, ale z tego pozoru wyłania się przed nami w całej swej nagości i pospolitości, i okazuje się czymś, co niczym nie różni się od jaźni właściwej, ani od aktora, ani od widza ${ }^{38}$.

Bogowie posiadają jedynie formę fantazmatycznej (łączącej cechy ludzie i boskie) indywidualności, nie mają zatem rzeczywistej jaźni. Ten abstrakcyjny moment wyraża się, zdaniem Hegla, w masce. Dla tragicznego bohatera maska jest czymś istotnym - aktor chowa się za nią, a ona definiuje jego postać jako ogólno-etyczny charakter. Bohater tragiczny posiada pewne indywidualne cechy, są mu one jednak narzucone z zewnątrz, w istocie stanowi on ahistoryczną i ponadindywidualną reprezentację, rodzaj scenicznego obrazu pozbawionego jednostkowego życia przywodzącego na myśl kolumnę, której brakuje żywej mimiki. Posiada on jaźń, która bez reszty podporządkowana została ogólności. Natomiast komiczny bohater rozpoznaje maskę jako pozór, potrafi nią grać, potrafi wznieść się ponad narzuconą przez nią formę subiektywności - w każdej chwili może ją zdjąć lub założyć, obnażając swą „nagość i pospolitość”39. Ten autoironiczny śmiech z własnej maski staje się wyrazem uwalniającej się samoświadomości, a odsłonięta przezeń „naga”

${ }^{38}$ G. W. F. Hegel, Fenomenologia ducha, s. 282-283.

${ }^{39}$ Tamże, s. 283. 
i „pospolita” podmiotowość urasta do rangi prawdziwej ogólności, ponieważ rozpoznaje się jako pierwiastek boski, jako „moc absolutną" ${ }^{\text {. }}$. Podczas, gdy w eposie i tragedii boskość wyobrażona jest jak to, „co ogólne i pozytywne, w przeciwieństwie do jednostkowej jaźni śmiertelnych"41, a zatem jako jej przeciwieństwo, komedia ukazuje jaźń bohatera jako konieczny los boskości - czyli przestrzeń, w której dokonuje się unicestwienie bogów olimpijskich będące rezultatem rozpoznania ich iluzoryczności.

Proces „wyludnienia nieba” greckiej mitologii rozpoczyna się, zdaniem Hegla, już na etapie eposu, ale osiąga apogeum dopiero w komedii. Warunkiem ukonstytuowania się samoświadomego podmiotu komicznego jest zatem „śmierć bogów”, którzy na podobieństwo Arystofanesowych chmur zamieniają się w „zanikające tchnienie” ${ }^{42}$. Podmiot jako „negatywna siła” ironicznie demaskuje politeistyczną sferę sacrum, ale również legitymizowane przezeń „królestwo etyczności”. W świecie komedii wszystko unosi się w oparach absurdu na mocy parodystycznej trawestacji, groteski i prześmiewczej deziluzji. Jedynym trwałym gruntem pozostaje tutaj naga podmiotowość. Tym samym w komedii do końca dochodzi rozwój ducha z formy substancji (etyczności ucieleśnionej w bezrefleksyjnych praktykach, normach i wierzeniach wspólnoty) do formy podmiotu ${ }^{43}$. Abstrakcyjny los, który rządził w eposie i tragedii, w komedii staje się negatywną siłą samej podmiotowości.

Według Hegla podmiot komiczny nie realizuje się wyłącznie w aktorze, który zmienia arystokratyczną maskę na maskę zwykłego człowieka, tak, że „widz czuje się w tym, co ogląda, zupełnie jak u siebie w domu i widzi, że to jego właśnie grają [na scenie]" ${ }^{4}$, ale również w widowni i w chórze będącym tubą prostego ludu. Istnieje zatem analogia między komiczną samoświadomością a grecką demokracją, czyli samoświadomie działającym demos. Stłumione w obrębie tradycyjnej etyczności roszczenia ludu zostają wykorzystane tutaj do tego, by wypełnić pustkę, jaka powstała po rozpadzie etycznej substancji i „wyludnieniu nieba”. W komedii uwalnia się tym samym głos ludu, który wcześniej (tj. w okresie poprzedzającym demokrację, ale również - na płaszczyźnie estetycznej - w eposie i tragedii) był pozbawiony ważności i uznania w sferze publicznej. Zmianie ulega również rola i znaczenie samego chóru. Hegel ma tutaj głównie na myśli funkcję parabazy, w której

\footnotetext{
40 Tamże, s. 285.

41 Tamże, s. 272.

42 Tamże, s. 284.

43 Tamże, s. 287.

44 Tamże, s. 285.
} 
chór zdejmował maski i wygłaszał przemowę w imieniu autora, zwracając się bezpośrednio do publiczności ${ }^{45}$. Przemowa ta dotyczyła zazwyczaj bieżących spraw publicznych, wyrażała poglądy komediopisarza niewolne od zjadliwej, bezceremonialnej krytyki. W tragedii chór starców reprezentował „prosty lud”, cechowała go jednak bezsilność, nie posiadał „mocy negatywności”, która jest w stanie aktywnie oddziaływać na świat przedstawiony, a zatem nie miał udziału w etycznych mocach. Tragiczny chór był zatem pasywną widownią, która solidaryzowała się z widownią tragedii i jedyną jego reakcją na tragiczny konflikt było „[...] puste życzenie uspokojenia i bezsilne nawoływanie do umiaru" ${ }^{46}$. Podobnie jak obserwującym przedstawienie widzom chórowi starców pozostawało przeniknięte doznaniem grozy i lęku współodczuwanie $\mathrm{z}$ aktorami, którzy stanowili jedyny podmiot działania. Chór tragiczny w przeciwieństwie do chóru komicznego był tym samym nieświadomy i nierzeczywisty, poddawał się bezwzględnej sile losu jak bohaterzy, ponieważ nie rozpoznał jeszcze tego, że sam jest dziejowym losem, podmiotem dziejów świata. Natomiast w komedii chór uwalnia się od swojej dotychczasowej niemocy dokładnie wtedy, gdy zaczyna pojmować siebie jako podmiot działania aktywnie wyrażający świadomość całej wspólnoty. Lud, „ogólna masa” zwykłych ludzi emancypuje się tutaj i osiąga dziejową sprawczość. Moment ten pokazuje, że komedia nie opiera się tylko na sile jednostkowej jaźni występującej na scenie, lecz na ogólnej zmianie zbiorowej samowiedzy, na upodmiotowieniu wykluczonych dotąd jednostek.

Podmiotowość komiczna nabiera tym samym charakteru intersubiektywnego, stanowi swoistą przestrzeń relacji między aktorem, odgrywaną przez niego rolą, a widownią i chórem. Symptomem tej zmiany jest zmiana funkcji chóru w procesie „wyludnienia nieba”: od epickiej tuby boskiej substancji, poprzez indyferentny, nieświadomy „głos starców”, który przypomina o obowiązkach obydwu etycznych mocy (prawa boskiego i ludzkiego), chór komiczny przekształca się w wyzwolony głos prostej mądrości ludowej, z której komedia bynajmniej się nie wyśmiewa ${ }^{47}$. Lud rozpoznaje się $\mathrm{w}$ chórze jako scenicznym przedstawicielu demos, który niejako przejmuje etyczne moce tragedii staje się działającym podmiotem substancjalnej etyczności.

\footnotetext{
${ }^{45}$ Por. G. W. F. Hegel, Wykłady o estetyce, t. 3, przeł. J. Grabowski, A. Landman, Warszawa 1967, s. 603.

${ }^{46}$ G. W. F. Hegel, Fenomenologia ducha, s. 275.

${ }^{47}$ Por. N. Hebing, Hegels Ästhetik..., s. 104.
} 
Ten zbiorowy podmiot Hegel kojarzy z dziejową "zasadą Sokratesa”, stwierdzając w Wykładach z filozofii dziejów: „[...] na począatku wojny peloponeskiej, ustami Sokratesa została swobodnie wypowiedziana zasada świata wewnętrznego, zasada absolutnej niezależności myśli w sobie" ${ }^{48}$. Sokrates stanowi zatem dla niemieckiego filozofa prototyp usamodzielnionej podmiotowości, która stawia pod znakiem zapytania etyczno-polityczny porządek polis. Jego krytyka obiegowych wyobrażeń i poglądów na temat wartości, jego wiara w autonomię i autarkię rozumu stała się „[...] czynnikiem rozkładu substancjalnego istnienia państwa ateńskiego" ${ }^{\prime 4}$, dlatego polites musieli postrzegać go jako zagrożenie. Jednakże, jak podkreśla Hegel, jego indywidualna postawa okazała się w perspektywie historiozoficznej wyrazem obiektywnego procesu potęgowania się siły indywidualności i rozpadu tradycyjnego etosu w świecie greckim. Niemiecki filozof zauważa przy tym, że tragicznej śmierci Sokratesa towarzyszyła ekspansja komizmu - „Pociągający i nawet w swym tragizmie pogodny jest ten beztroski humor i lekkomyślność, z jaką Ateńczycy odprowadzają do grobu swoją etyczność. Wyższe tendencje nowej kultury przejawiają się $\mathrm{w}$ tym, że lud pokpiwa sobie $\mathrm{z}$ własnych głupstw, znajdując wielką przyjemność w słuchaniu komedii Arystofanesa, które w treści swej zawierają pełne goryczy szyderstwa, a przy tym noszą na sobie znamię najswawolniejszego humoru"50.

Podsumowując, możemy stwierdzić, że w Heglowskiej wykładni komedia ukazuje na planie estetycznego przedstawienia proces, który dokonał się w realnym życiu Sokratesa-filozofa. Komiczna podmiotowość uwalnia się spod jarzma greckiej mitologii i etycznych mocy, zyskując samoświadomość - nawet jeśli uwolnienie to nie jest realne, lecz ma charakter pozoru, czy też zaaranżowanego na scenie teatru „marzenia sennego”. Indywidualność śni zatem w komedii sen o swojej samodzielności i autonomii, który w realnym życiu zrealizował jej realny tragikomiczny odpowiednik - Sokrates. W obydwu przypadkach dochodzi do zniesienia substancji etycznej, którego rezultatem jest powstanie „nagiej”, pozbawionej oparcia w obiektywnym porządku etycznym podmiotowości. Samoświadoma, zdana tylko na samą siebie jaźń odkrywa w sobie próżnię, którą próbuje zapełnić „czystymi myślami o dobru i pięknie"51. Pozbawiona zwyczajowych maksym postępowania, musi ona za-

\footnotetext{
${ }^{48}$ G. W. F. Hegel, Wykłady z filozofii dziejów, t. 1, przeł. J. Grabowski, A. Landman, Warszawa 1958, s. 78.

${ }^{49}$ Tamże, s. 80.

50 Tamże, s. 79-80.

${ }^{51}$ G. W. F. Hegel, Fenomenologia ducha..., s. 284.
} 
tem za pośrednictwem czystej refleksji wysnuć z siebie zasady, a następnie je uzasadnić i wcielić w życie. Według Hegla podmiotowość komiczna nie jest jednak w stanie tego samodzielnie dokonać:

Czyste myśli o pięknie i dobru dają więc komiczne widowisko przez to, że uwolnione od mniemania, które zawierało w sobie zarówno ich określoność co do treści, jak ich określoność absolutną - stałość świadomości - stają się puste i dlatego właśnie okazują się grą mniemania i dowolności przypadkowego indywiduum ${ }^{52}$.

Komedia jako siła negatywności działa tym samym destabilizująco, ponieważ pozostawia widownię bez nowej trwałej pozycji, destruuje istniejący porządek wartości, nie dając w zamian nowego. Substancja, która w tragedii była jeszcze rozszczepiona na konkurujące ze sobą moce etyczne, w komedii staje się jednością w ramach demokratycznej wspólnoty, ale nie udaje się tutaj w żaden sposób wyrazić tej nowej etyczności. W tym sensie komedia wydaje się stanowić dla Hegla ślepy zaułek, pozbawiony jednak jakiegokolwiek śladu trwogi i lęku. Śmiech obnaża wprawdzie nicość panującego ładu, ale nie stanowi dla niego realnego zagrożenia - „Jest to powrót wszystkiego, co ogólne, do pewności samego siebie, pewności, która przechodzi w zupełny brak obawy przed tym, co obce, $\mathrm{w}$ widzenie jego nieistotności oraz w zadowolenie świadomości z siebie i wprawianie siebie w stan zadowolenia, jakiego nigdzie poza tą komedią już znaleźć nie można"53. Dlatego też w perspektywie Fenomenologii ducha religia sztuki zwieńczona komedią musi przejść w fazę religii jawnej, gdzie duch w postaci panteistycznego boga chrześcijaństwa inkarnuje się w człowieka, a zatem nie tyle jest reprezentowany przez coś lub przez kogoś, ile staje się konkretnym, ucieleśnionym podmiotem. Inkarnacja wiecznej istoty w tym świecie oznacza, że równocześnie znika ona $\mathrm{z}$ „tamtego świata” transcendencji, a w pewnym sensie znika również sama transcendencja. Wraz z śmiercią Chrystusa na krzyżu (czyli śmierci jaźni, podmiotu, który ucieleśnia istotę) umiera również transcendentny bóg, który dzięki temu staje się częścią konkretnej rzeczywistości ludzkich podmiotów. Nie oznacza to jednak prostej eliminacji transcendencji, lecz afirmację jej realnej, konkretnej egzystencji. Komedia poprzedza ten proces, ale pozbawiona jest dialektycznego ruchu, który obejmuje inkarnację boskiej istoty, jej śmierć

\footnotetext{
52 Tamże, s. 285.

${ }^{53}$ Tamże, s. 286.
} 
i zmartwychwstanie. Absolutem staje się w niej sam podmiot, a duch wyparowuje $\mathrm{w}$ formie fantazmatycznych chmur, jak ilustruje to Arystofanes.

Innymi słowy, również w komedii właściwym czynnikiem sprawczym jest boska substancja, która posługuje się siłą negatywności podmiotu, by przekształcić się w to, co jednostkowe. Jak pisze Hegel: „Do świadomości komicznej wraca wszelka istota boska, albo inaczej mówiąc, świadomość ta jest całkowitą eksterioryzacją substancji” ${ }^{54}$. To znaczy, w komicznej „szczęśliwej świadomości" nie tyle substancja wyobcowuje się od jaźni, podmiotu (co występuje w „świadomości nieszczęśliwej”), lecz substancja wyobcowuje się od siebie samej i jest to jedyna droga, na której może ona osiągnąć samoświadomość i prawdziwe życie. Komedii nie należy zatem interpretować jako historii wyobcowania podmiotu, lecz jako historię wyobcowania substancji, która stała się podmiotem ${ }^{55}$. Komiczna świadomość wykorzystuje swoją siłę negacji, by obnażyć różne postaci abstrakcyjnej ogólności jako puste i przypadkowe wytwory umysłu, a tym samym przygotowuje grunt dla religii jawnej.

Ten moment koncepcji Hegla wydaje się niezwykle płodny dla zrozumienia konstrukcji komedii, nawet jeśli odrzucimy całościowy zamysł jego systemu. Komizm polegałby więc nie na prostym przeciwstawieniu tego, co konkretne temu, co abstrakcyjne, a następnie na prześmiewczej negacji tego ostatniego, lecz raczej na ukazaniu tego, co abstrakcyjne w postaci konkretu (substancja, która stała się podmiotem) ${ }^{56}$. Komedię możemy w tym kontekście opisać jako pogodny „taniec śmierci” rozmaitych postaci Sittlichkeit (w tym również upadek tragedii), który neguje, a zarazem zachowuje etyczną substancję, sprowadzając ją na powrót do pozycji podmiotu jako jej właściwego twórcy. Jak pisze Hebing: „Dopiero wraz ze zniesieniem substancjalnej całości narodził się ten podmiot jako wcielenie nowej zasady nowoczesnej podmiotowości" ${ }^{57}$.

W następnym paragrafie spróbujemy zilustrować wskazane powyżej, najważniejsze elementy Heglowskiej interpretacji komedii na przykładzie Chmur Arystofanesa, wysuwając równocześnie szereg tez o charakterze antropologicznym dotyczących natury komizmu.

\footnotetext{
${ }^{54}$ Tamże, s. 289.

${ }^{55}$ Por. A. Zupančič, The Odd One In: on Comedy, London 2007, s. 39.

${ }^{56}$ Por. tamże.

${ }^{57}$ N. Hebing, Hegels Ästhetik..., s. 112.
} 


\section{Antropologiczne implikacje komizmu Chmur Arystofanesa}

Według Hegla komedia ukazuje wyższy stopień rozwoju samowiedzy ducha aniżeli tragedia. Podmiotowość komiczna uwalnia się od mocy mitycznego fatum i urasta do rangi prawdziwej ogólności, ponieważ rozpoznaje się jako pierwiastek boski, jako „moc absolutna”. W akcie uwalniania się od zewnętrznych potęg porządku symbolicznego podmiot zyskuje „negatywną siłę" i wykorzystuje ją do ironicznego zdemaskowania politeistycznej sfery sacrum (chmury jako parodia olimpijskich bogów), ale również legitymizowanego przez nią „królestwa etyczności” - w Chmurach obnażona zostaje zarówno niemoc tradycyjnego, arystokratycznego etosu, jak i zwodniczość sofistycznego dyskursu (agon mowy sprawiedliwej i niesprawiedliwej) ${ }^{58}$. Spróbujmy zastanowić się, czym charakteryzuje się komiczna podmiotowość, przyjmując za punkt odniesienia perspektywę antropologii filozoficznej.

Hegel poprzestaje na wskazaniu dwóch jej własności - samoświadomości, która otwiera przed nią "absolutną wolność” oraz „pełni życia”, którą może się delektować bez poczucia lęku i zagrożenia. Podmiotowość komiczna powstaje w intersubiektywnej przestrzeni utworzonej za pośrednictwem złożonej sieci identyfikacji widowni z komicznymi personami. Identyfikacja ta ma, inaczej niż w tragedii, charakter powierzchowny, jest kapryśna i zmienna ustaje, gdy, na przykład, komiczne postaci zaczynają budzić odczucie pogardy i lekceważenia, by chwilę później powrócić, gdy zbieg okoliczności ukazuje "sympatyczną stronę" ich charakteru lub zachowania. Na skutek gry przypadku, nieustannej zmiany akcji i kierunku identyfikacji podmiotowość widza ulega rozproszeniu, traci spójność i władzę wydawania sądów. Innymi słowy, traci ona w ten sposób swoją „substancję", staje się ruchem, konfiguracją zmiennych odniesień, które rozprzęgają również język codziennej, „,racjonalnej” narracji, za pomocą której odbiorcy usiłują nadać jednolity i ciągły charakter swojemu doświadczeniu. Komedia to przecież w najogólniejszym sensie pełna pomyłek, lapsusów gra nonsensu, to "antylogika” odwrotności, przesunięć, „,rzeczy na opak”, to wizja, w której do głosu dochodzą stabuizowane, niestosowne bądź zakazane treści. Komedia odsłania zatem mroczną, wstydliwą czy absurdalną stronę oficjalnej rzeczywistości, którą można bezkarnie obserwować z pozycji bezpiecznego dystansu. Dlatego komiczna

${ }^{58}$ Por. szczegółową analizę agonu: D. O’Regan, Daphne. Rhetoric, Comedy and the Violence of Language, Oxford 1992, s. 89-114. 
postać, chociaż wydawałoby się tak różna od widza, staje się nieuchronnie krzywym zwierciadłem, w którym on się przegląda i przynajmniej przez chwilę uzmysławia sobie obecną w nim samym irracjonalność. W komedii nie chodzi jednak o rozumienie, o zamknięcie koła hermeneutycznego, ale właśnie o wprowadzenie go w niepowstrzymany, rozedrgany, nieciągły ruch, który ujawnia szczeliny, pęknięcia w symbolicznym porządku naszego życia. Zdysocjowana komiczna podmiotowość wykracza, a raczej jest „wyrzucana” poza granice wyznaczone poczuciem jednostkowej tożsamości i w tym sensie ma charakter ekstatyczny, na co zwrócił uwagę już Platon, potępiając mimetyzm wywołany recepcją sztuki dramaturgicznej i poezji5 ${ }^{59}$.

Arystofanes świadomie wykorzystuje mimetyczne odruchy widowni, zmienną grę identyfikacji, aby wyzwolić quasi-misteryjną przemianę podmiotowości komicznej. Dobrym przykładem jest scena poprzedzająca wstąpienie Strepsjadesa do myślarni.

$\mathrm{Na}$ początku widzimy Strepsjadesa, który używając mało wyszukanego, ekskrementalno-genitalnego humoru, drwi wyraźnie z groteskowych uczniów Sokratesa. Ich zachowanie potwierdza obiegowy obraz oderwanego od życia i oddającego się absurdalnym dociekaniom filozofa (vide śmiech trackiej służącej z Talesa) ${ }^{60}$ oraz sofisty - oszusta i krętacza. Sam Sokrates przedstawiony zostaje jako ekscentryk działający w ukryciu, który mami swoich uczniów wizją „wyższych” problemów, ograbiając ich zarazem z prawdziwej substancji ich społecznego życia. Widownia przejmuje zatem początkowo spojrzenie prostodusznego bohatera, jednakże chwilę później, kiedy ujawnia on całkowitą niezdolność do uczenia się i abstrakcyjnego myślenia, musi porzucić identyfikację $\mathrm{z}$ jego spojrzeniem i w ten sposób pośrednio również zakwestionować komiczną postawę, którą on zdawał się dotąd ucieleśniać. Drwiący stają się niespodziewanie obiektem drwiny, dlatego zmieniają pozycję w komicznej konstelacji. Wcześniejszy śmiech ze studentów staje się zawstydzający i podejrzany, to z kolei zmusza widownię do rewizji swojej wcześniejszej postawy wobec myślarni. Strepsjades i jego reakcje stają się ostrzeżeniem. Widzowie, chcąc nie chcąc, umieszczają się w perspektywie Sokratesa obnażającego głupotę Strepsjadesa. Problem w tym, że widownia nie może całkowicie porzucić swojej identyfikacji z komediowym idiotą, śmiejąc się z niego, śmieje się z samej siebie. Komizm przybiera tutaj

${ }^{59}$ R. Michalski, Antyczne źródła pojęcia mimesis, „Filo-Sofija”, nr 5, Bydgoszcz 2005, s. 45-64.

${ }^{60}$ H. Blumenberg, Das Lachen der Thrakerin. Eine Urgeschichte der Theorie, Frankfurt am Main 1987. 
refleksyjną postać, testuje śmiech, który sam wywołuje. Kierunek identyfikacji wielokrotnie zmienia się $\mathrm{w}$ toku przedstawienia. Kiedy niczym deus ex machina na scenie pojawia się paratragiczny, bujający w koszu nad ziemią Sokrates i wyjaśnia Strepsjadesowi przyczyny swego osobliwego locum, doprowadza swój logos do granic absurdu. „Bo gdybym z ziemi badał rzeczy górne / Nic bym nie znalazł, bo ziemia przyciąga / Siłą do siebie cały opar myśli. / Podobnie dzieje się, jak wiesz z rzeżuchą" (w. 231-234) ${ }^{61}$. Strepsjades ma problem ze zrozumieniem tego mechanizmu i bezmyślnie powtarza i konkretyzuje ostatnie słowa: „Że myśli ciągną opar do rzeżuchy?” (w. 236). Arystofanes używa tutaj dowcipu o podwójnym dnie. Śmieszy w nim Strepsjades niezdolny do abstrakcji, ale również bardziej intrygujący, bo pełen pretensji fałsz rozumowania Sokratesa. Okazuje się więc, że wypowiedź Sokratesa i replika Strepsjadesa są w równym stopniu produktem logosu oczyszczonego z logicznego sensu. Śmiech zaciera granice pomiędzy dwiema postaciami, następuje chwilowe wyzwolenie podmiotu od przymusu identyfikacji, a z ducha homerycki asbestos gelos przypieczętowuje dopiero co zdobytą wolność.

Jak wskazuje Hegel, podmiot wyłaniający się w przestrzeni komicznej utwierdza się w sobie i zostaje zawieszony w rozkosznym vertigo bez żadnego punktu oparcia, a my dodajemy, że w tym stanie dochodzi do eksplozji nadmiaru gwałtownie odblokowanej energii witalnej. Życie ujarzmione dotąd imperatywem przetrwania (Strepsjades desperacko poszukujący wyjścia z finansowej opresji) i abstrakcyjnym dyskursem wiedzy samej dla siebie (Sokrates) znajduje nagle ujście w śmiechu, otwierając perspektywę pełniejszego, jednostkowego istnienia. To ważny moment, którego nie należy mylić z prostym wyzwoleniem ślepych, zahamowanych popędów. Za Heglem należałoby raczej powiedzieć, że w śmiechu substancja staje się podmiotem. Śmiech wymaga bowiem refleksyjnego rozpoznania. Abstrakcyjna ogólność (tutaj dyskurs oderwany od pragnienia) dokonuje aktu samorozpoznania i samozniesienia. W rezultacie podmiot nabiera witalnych mocy i zyskuje zdolność do samostanowienia. Według Hegla to poczucie absolutnej wolności może dać jedynie chwilową rozkosz i nic więcej. My natomiast ryzykujemy tezę, że komediowe oczyszczenie i wzmocnienie podmiotowości mogłoby posłużyć za punkt wyjścia do skonstruowania nowego modelu antropologicznego, w którym człowiek uwalnia się od lęku przed śmiercią, od biernego podporządkowania sile konieczności.

${ }^{61}$ Numery wersów w nawiasach odsyłają do: Arystofanes, Komedie, przeł. J. Ławińska-Tyszkowska, Wrocław 1991. 
Ważnym elementem transformacji komediowego podmiotu jest mimetyczna moc tytułowych chmur, które odzwierciedlają swoim kształtem pragnienia i oczekiwania tych, którzy na nie patrzą i kogo one widzą. Strepsjades odbity w eterycznym lustrze paraolimpijskich bogiń przeżywa $\mathrm{w}$ parodystyczny sposób chwilę misteryjnej trwogi w trakcie inicjacji do szkoły Sokratesa. Wyłaniające się zza sceny chmury wydają się zapowiadać zmianę jego życia w postaci deszczu, który uwolni jego dotychczasowe lęki i pragnienia. Tymczasem niedorzecznego mistę ogarnia lęk przeszywający trzewia: „[...] aż trzęsę się z przerażenia; / I czy się godzi czy też się nie godzi, już teraz, / zaraz... się zesram" (w. 296-297). Arystofanes przywołuje cielesność, gdy mowa jest o czymś wzniosłym, pokazując w przekorny sposób, że komedia otwiera perspektywę szerszą od tej, którą może dostarczyć prosta parodia. Śmiejąca się widownia rozbrojona przez chytrą wulgarność sceny zostaje niepostrzeżenie wprowadzona $\mathrm{w}$ ruch komediowej refleksji - w grę zwierciadlanych odbić (refleksów) będącą wizualnym przekładem logosu. Metamorficzne chmury posiadają zdolność wytwarzania obrazowych znaków, które ukazują ludzkie przywary jako zwierzęce postaci, kontemplację jako fizjologiczną reakcję, manię jako erotyczne napięcie. Jak powiada Sokrates: „one wszystkie potrafią stać się kim zapragną” (w. 348), są zatem zakorzenione w ludzkiej naturze. Komediowy logos chmur wykazuje elastyczność pozwalającą mu we właściwym momencie (w swoistym komediowym kairos) odzwierciedlić nie tylko charakter postaci, ale również sens reprezentowanych przez nie poglądów i postaw. Stanowiska sofistów, filozofów przyrody, zwolenników tradycyjnego ładu uzyskują tutaj obrazową wyrazistość i stają się narzędziem przemiany abstrakcyjnej ogólności w konkretną podmiotowość. To, co wzniosłe, intelektualne, otoczone splendorem autorytetu zostaje zdegradowane do poziomu gastryczności (retoryka jako sekwencja pierdnięć etc.) i rozprasza się w oparach absurdu, odsłaniając nagie życie wzmożone do tego stopnia, że wyzwala ono nową formę refleksji, o której wspomina Hegel.

Zatrzymajmy się w tym punkcie. W kluczowym dla sztuki agonie dwóch mów wygrywa logos niesprawiedliwy (hetton logos), ale cała komedia pokazuje, że sofistyczna retoryka oderwana od rygoru sophrosyne, rozumnej samokontroli, staje się pastwą irracjonalnych, ślepych popędów. W parabazie Arystofanes wyraźnie podkreśla, że porażka pierwszej wersji Chmur była efektem jego złudnej wiary w moc zręcznego słowa, w powab hetton logos. Zauroczony grami słownymi nie odpowiedział (i nie chciał odpowiedzieć) na potrzebę wulgarnej gastryczności, jakiej oczekiwała od niego widownia. 
Z kolei porażka sprawiedliwego logosu (kreitton logos) w agonie uwidacznia jego największą słabość - niezdolność do krytycznej refleksji. Komedia nie jest zatem apologią naturalnego człowieka, który uwalnia się spod władzy instrumentalnego dyskursu. Na planie filozoficznym należałoby ją raczej odczytać jako manifest nawołujący do stworzenia, odkrycia (?) nowego, „zdrowego" języka łączącego w sobie sophrosyne z krytycznym namysłem. Końcówka sztuki pokazuje w naszej interpretacji, że tego rodzaju innowacyjny logos budzi się w uwolnionym życiu, w nadmiarze energii witalnej oczyszczonej z uwikłań w gry językowe i więzy bezrefleksyjnej tradycji. Pierwszym przejawem owej „apokatastasis” popędów w nowym porządku logosu jest śmiech - triumf tego, co jednostkowe nad abstrakcyjną ogólnością, dzięki któremu substancja staje się konkretnym podmiotem. Dlatego komizm postaci Strepsjadesa nie polega na tym, że jego umysł opanowuje bałamutna, fałszywa idea, która rozbija się w konfrontacji z realiami życia, tak jak gdyby stanowiła ona fałszywe, groteskowe przebranie, które nie pasuje do autentycznego, ludzkiego charakteru komicznego bohatera. Śmieszność tkwi tutaj raczej w tym, że abstrakcyjny element stanowi w istocie integralną część jednostkowej "natury” Strepsjadesa. Wyobcowana substancja (sofistyczna retoryka), która początkowo jawi się jako „zewnętrzna moc”, bezskutecznie narzucana przez Sokratesa, wyraża w finale najgłębszą część podmiotowości Strepsjadesa jako „człowieka naturalnego” - pragnienie uwolnienia się z opresji za pośrednictwem oszustwa. Kiedy następuje moment rozpoznania substancji jako podmiotu, ten ulega komicznemu przekształceniu, o którym pisaliśmy powyżej. Substancja traci abstrakcyjny, zewnętrzny wobec jednostki charakter, upodmiotawia się, wywołując proces komicznej transformacji Strepsjadesa, w którym uwalnia się on od wcześniejszej, czysto popędowej natury pragnienia, a zarazem od zewnętrznej mocy sofistycznego logosu.

Nie oznacza to jednak, że główny bohater staje się w finale rozumną istotą, wzorem komediowej paideji. Arystofanes ukazuje jedynie jego przemianę, bez przesądzania o tym, co z niej może wyniknąć. Istotna jest tutaj sama transformacja. Należy przy tym zwrócić uwagę na to, że Strepsjades nie zostaje ukazany jako typowy komiczny głupek - jest wprawdzie prostolinijny, nieokrzesany i nierozumny, ale w żadnym wypadku nie można go uznać za osobę fałszywą. Mimo groteskowych cech charakteru przypomina pod wieloma względami postać przeciętnego mieszkańca polis, który przeniósł się ze wsi do miasta, daremnie szukając szczęścia. W istocie wzbudza współczucie, przeżywa w końcu poważną życiową katastrofę - nieudane małżeństwo, nie- 
pokorny, zepsuty moralnie syn i długi zaciągnięte wbrew jego woli. Te biograficzne szczegóły nie prowadzą do „schłodzenia serca”, jakby chciał Henri Bergson, wręcz przeciwnie, skłaniają widza do sympatii, do pewnego rodzaju solidarności z ofiarą zewnętrznych okoliczności. Nikczemność moralna Strepsjadesa ukazana $\mathrm{w}$ komedii ma $\mathrm{w}$ sobie więcej $\mathrm{z}$ desperacji tonącego, który chwyta się brzytwy, aniżeli z zachłanności bezmyślnego drania. Poddaje się on sile złego logosu, ponieważ nigdzie nie znajduje ratunku, ślepy na konsekwencje planowanej przez siebie nieuczciwości, cierpi coraz bardziej, nawet jeśli jest to tylko ból komiczny. W tym sensie możemy powiedzieć, że dzieło Arystofanesa subtelnie odsłania kolejne etapy niesubtelnego wikłania się bohatera w nieuczciwość.

Śmieszny Strepsjades nie odbiega tak bardzo, jak wspomnieliśmy, od potencjalnego widza, posiada bowiem cechy, które stanowią punkty zaczepienia dla komediowej identyfikacji - wykazuje pewną dozę samoświadomości oraz moralnej i intelektualnej przenikliwości, o czym świadczy chociażby to, że rozpoznaje zarówno swoją desperację, jak i groteskowość własnego położenia, lamentując nad własnym losem, a zarazem drwiąc z samego siebie (w. 41-55). Również jego spostrzeżenia dotyczące myślarni ujawniają ironię i sarkazm (w. 95).

Kiedy w końcowej scenie sztuki podkłada ogień na dachu myślarni, a jeden z uczniów Sokratesa pyta się, co robi, ten odpowiada: „Co robię, prowadzę subtelny dialog z belkami tej chaty” (w. 1495-1496). To zamykające komedię komiczne współgranie logosu i ergonu, czyli cyniczne przełożenie zasad logicznego dyskursu na język czynu wydaje się dostarczać negatywnego obrazu, który sugeruje ich konstruktywne połączenie. Finałową furię Strepsjadesa, jego bezkompromisową zemstę na sofistycznym logosie, można za Bernardem Freydbergiem, odczytać jako komiczne narodziny Dionizosa, patrona sztuki komediowej, przynoszące oczyszczenie instynktownych impulsów i uwolnienie z sieci zwodniczego dyskursu ${ }^{62}$. Symboliczny "pożar” abstrakcyjnej ogólności byłby zatem równoznaczny z obudzeniem siły Erosa zamkniętego do tego momentu w żelaznej klatce partykularnych potrzeb i interesów. Obsesyjne, nie liczące się z zasadą rzeczywistości pragnienie wyjścia z długów, które motywowało przez całą komedię Strepsjadesa, dociera do punktu, gdzie otwiera się perspektywa pełniejszego życia. Arystofanes nie podpowiada nam jednak, na czym miałoby ono polegać, pokazuje natomiast bezgraniczną radość życia w obliczu największej nawet głupoty. Dostrzega to

${ }^{62}$ B. Freydberg, Philosophy and comedy. Aristophanes, Logos and Eros, Bloomington 2008, s. 5. 
Hegel, pisząc: „Kto nie czytał Arystofanesa, z trudnością może sobie wyobrazić, jak człowiekowi może być po świńsku dobrze (sauwohl)" ${ }^{63}$. Ów gwałtowny zysk rozkoszy, o którym rozprawiał tyle również Sigmund Freud, pisząc o śmiechu, nie jest wyłącznie bezrefleksyjną erupcją stłumionej energii witalnej, ponieważ łączy się z „głębokim wglądem”, z gwałtownym wzrostem ludzkiej samowiedzy, na co wyraźnie zwraca uwagę Hegel ${ }^{64}$.

Autor Chmur manipuluje emocjami widza, ponieważ chce go „porwać” i pokazać mu na pograniczu ukazanej w krzywym zwierciadle ludzkiej katastrofy głębię człowieczeństwa. Pod komiczną powierzchownością Strepsjadesa, jego pospolitością, moralnymi przywarami ukrywa się bowiem wyzwalająca siła Errosa, do której prowadzi via regia niepohamowanego śmiechu. Gelos działa tutaj jak ładunek wybuchowy rozsadzający porządek logosu. Tym, co pozostaje po jego eksplozji, wydaje się żywa tkanka języka, ogołocona ze struktury i przepuszczona przez ludzkie trzewia.

W agonie dwóch logosów język niesprawiedliwy reprezentuje relatywizm, wiarę w język jako najlepsze narzędzie przetrwania, które umożliwia osiągnięcie życiowego sukcesu i zdobycie sławy. Chmury występujące w roli chóru pozornie umacniają tę wiarę, pozwalając wygrać mu rywalizację z bezsilnym logosem sprawiedliwym, opartym na bezrefleksyjnym uznaniu autorytetu tradycji. Jednakże komedia $\mathrm{w}$ kolejnych scenach i dialogach obnaża równocześnie miałkość sofistycznej retoryki, pokazując, że sam język, nawet najbardziej wyrafinowany, traci władzę, gdy odrywa się od sfery ludzkich pragnień. W tym kontekście Daphne O’Regan przywołuje postać Peitho, bogini perswazji, towarzyszki Afrodyty, która nadaje mowie moc uwodzenia. Sukces Afrodyty, stwierdza badaczka, „[...] przypomina nam, że wszelka perswazja (peitho) powinna być rozpatrywana jako zintegrowana całość, jako kontinuum, w obrębie którego to, co boskie i to, co świeckie, erotyczne i nieerotyczne tworzą jedność”65. O’Regan stawia tezę, że wzrastający prymat retoryki jako technicznej manipulacji słowami doprowadził w $\mathrm{V}$ w. p.n.e. do wyparcia starszego, erotycznego aspektu peitho (perswazji jako prewerbalnego logosu), który odwoływał się bezpośrednio do ludzkich pragnień.

${ }^{63}$ G. W. F. Hegel, Vorlesungen über die Ästhetik III, [w:] tenże, Werke, Bd. 15, Frankfurt am Main 1990, s. 553. Modyfikuję przekład Janusza Grabowskiego i Adama Landmana, którzy oddali ten ustęp następująco: „Kto go nie czytał, z trudnością może sobie wyobrazić, jak lekko może być człowiekowi na duszy", [w:] G. W. F. Hegel, Wykłady o estetyce, t. 3, przeł. J. Grabowski, A. Landman, Warszawa 1967, s. 660.

${ }^{64}$ G. W. F. Hegel, Wykłady o estetyce, s. 661.

${ }^{65}$ D. O’Regan, Daphne, Rhetoric, Comedy..., s. 24. 
W rezultacie zakłócona została naturalna równowaga w rozumieniu ludzkich motywacji.

Dla naszej interpretacji ważne jest to, że Strepsjades całkowicie pozbawiony retorycznych umiejętności oraz zdolności do abstrakcyjnego myślenia, potrafi jednak posługiwać się erotyczną (w szerokim znaczeniu) perswazją na przykład, kiedy namawia syna do nauki w myślarni, z dobrym skutkiem odwołuje się do imperatywu miłości synowskiej (w. 82). Jego intelektualna i werbalna impotencja czyni go życiowym nieudacznikiem, jednakże słabość ta powoduje zarazem, że utrzymuje on bezpośredni kontakt ze sferą elementarnych, niepoddanych sublimacji pragnień. Brak refleksyjnego dystansu do swoich potrzeb zamienia go w niewolnika ślepych impulsów, który nie licząc się z możliwymi skutkami własnych decyzji, poddaje się biernie mechanice komediowej akcji. Pasywność Strepsjadesa, jego impotencja ułatwia mu jednak zrzucenie ciężaru abstrakcyjnej ogólności i czyni go idealnym medium dla „komediowego Dionizosa”, który w końcowej scenie palenia phronisteron wskrzesza w nim errotyczną moc autoafirmacji. Strepsjades po raz pierwszy podejmuje tutaj suwerenną decyzję i doświadcza smaku „absolutnej wolności” (Hegel). Komedia zdaje się sugerować, że ten wyzwolicielski akt dokonany jest w imię tradycyjnych wartości, jednakże odnowiony Strepsjades nie powróci już do tego samego świata. Klęska tradycyjnego logosu w agonie i obnażenie fałszu logosu sofistycznego nie pozostawiają mu żadnych złudzeń. Finał sztuki ukazuje więc przemianę bohatera $\mathrm{z}$ ulegającego ślepym pragnieniom i retorycznym sztuczkom życiowego nieudacznika w wolny, przepełniony radością podmiot. To wizja końca dotychczasowego świata, która otwiera perspektywę nowych możliwości, daje nadzieję, choć nie oferuje żadnych gotowych recept ${ }^{66}$.

Chmury można więc odczytać jako rodzaj swobodnego eksperymentu myślowego, który skłania do dokonania nowej syntezy, sugerowanej w sztuce jedynie aluzyjnie. W przypadku Strepsjadesa pozytywna perspektywa, jakiej dostarcza komedia, wskazuje na wypunktowane przez Hegla momenty uwolnienia podmiotu komicznego od tyranii abstrakcyjnej ogólności i przekształcenia substancji $\mathrm{w}$ podmiot, ale również, co próbowałem uzasadnić - na moment wyzwolenia witalnego potencjału człowieka, owego „więcej życia” (Nietzsche), czy też Errosa (Bielik-Robson) przeciwstawiającego się terroryzującej władzy śmierci, lęku i konieczności. Finał komedii przed-

${ }^{66}$ Por. M. Nussbaum, Aristophanes and Socrates on Learning Practical Wisdom, „Yale Classical Studies", vol. 26, 1980, s. 43-97. 
stawia więc pojednaną ze sobą, doświadczającą rozkoszy podmiotowość, w której budzi się niewykorzystany, kreatywny potencjał mowy i działania.

Komediowa wizja człowieka sugeruje, że nie musimy $\mathrm{z}$ rezygnacją poddawać się widmu nieuchronnej śmierci, skończoności i kontyngencji istnienia, ponieważ możemy wykorzystać te graniczne doświadczenia do spotęgowania w pełni zindywidualizowanego życia. Komedia inscenizuje proces ponownych narodzin człowieka, w których wyzwala się on z porządku pier wszej natury (pragnień podporządkowanych imperatywowi przetrwania) i drugiej natury (substancji ducha obiektywnego, czyli zautonomizowanych, oderwanych od jednostki treści i instytucji kulturowych). Te komediowo-dionizyjskie narodziny człowieka otwierają przed nim perspektywę nowej, konkretnej (a nie abstrakcyjnej jak dwie pierwsze) natura naturans, ugruntowanej w niepowtarzalnej, jednostkowej egzystencji, anarchicznej i rebelianckiej, ale przenikniętej krytyczną refleksją, która chce dobra wspólnego w imię radości życia.

Jak podkreślał już Arystoteles, tragedia koncentruje się na działaniu (pra$x i s$ ), które zachowuje w niej linearność, spójność, mimo punktów zwrotnych i zapętleń akcji. Natomiast w komedii działanie jest rozproszone, bezładne albo podporządkowane mechanice odwrotności i repetycji - w obydwu wariantach zakłóca więc logikę, jaką kieruje się „naturalne”, „sensowne” funkcjonowanie w świecie. Wydaje się jednak, że nie chodzi tutaj tylko o prostą deformację, o odwrócenie porządku codzienności. Chaos, nietypowość reakcji postaci komicznych, ale również ich przewidywalna mechaniczność pokazują raczej, że w życiu człowieka niemożliwe są linearne, logiczne ciągi działań. Komedia demaskuje to wyobrażenie jako fałsz, a tym samym odrzuca terror sensu, stawiając na produktywny bezsens. Sens nanizany na siatkę języka, wpompowany w partykularny projekt życiowy polega zazwyczaj na zwykłej reprodukcji tego, co już było, czyli, jak zdaje się mówić komedia, jest ostatecznie bezsensem pozorującym Sens. Dlatego Arystofanes świadomie burzy pozorny ład porządku symbolicznego i stawia na nonsens jako źródło twórczego myślenia. W przekorny sposób pokazuje, że głębia intuicyjnego poznania może rodzić się jedynie w pęknięciach, szczelinach skostniałej fasady sensu narzuconego przez oficjalny dyskurs. Takie twórcze rozpoznanie otwierające nowe horyzonty rozumienia możliwe jest dzięki wpisanej w naszą kondycję „nieskończoności”, którą konstytuuje nadmiar nieskanalizowanej energii popędowej i nieokreślonych, a do tego niezgłębialnych pobudek działania, ale również otwartość horyzontu możliwych doświadczeń, które mogą być naszym udziałem, a wreszcie nieprzewidy- 
walność skutków naszych decyzji. Komediowe misterium ujawnia, że owa potencjalnie kreatywna „nieskończoność” jest stałym aspektem wszelkich działań człowieka, doświadczamy jej cały czas jako pewnego tła, z którego nie zdajemy sobie sprawy, a które może nas skłonić albo do tragicznego poddania się fatum i kontyngencji życia, albo do „komicznego” wyzyskania konstytucjonalnego ekscesu naszej natury w procesie samoafirmacji i wzmagania życiowej energii.

Jak zauważa George Steiner, tragedia grecka kończy się przygnębiającą klęską bohatera i nie odsłania żadnej głębszej, ukrytej celowości jego upadku, ponieważ nie zna idei zadośćuczynienia czy reparacji poniesionego w przeszłości cierpienia (jak chrześcijaństwo nadające mu moralne, czy religijne znaczenie $)^{67}$. Pomiędzy działaniem a wiedzą o jego celowości rozpościera się tutaj otchłań niewiedzy naznaczonej piętnem gorzkiej ironii. Dlatego tragedia konfrontuje nas ostatecznie z brakiem sensu, natomiast komedia oferuje nam radosny bezsens, który otwiera przed nami widnokrąg nowego, choć nieprzewidywalnego znaczenia. To niewątpliwie utopijna, pełna nadziei i zapewne mglista perspektywa, której należałoby się jeszcze przyjrzeć $\mathrm{z}$ większą wnikliwością.

\section{Bibliografia}

Arystofanes, Komedie, przeł. J. Ławińska-Tyszkowska, Wrocław 1991.

Bielik-Robson A., „Na pustyni”. Kryptoteologie późnej nowoczesności, Kraków 2008.

Bielik-Robson A., Erros, Mesjański witalizm i filozofia, Kraków 2012.

Blumenberg H., Das Lachen der Thrakerin. Eine Urgeschichte der Theorie, Frankfurt am Main 1987.

Freydberg B., Philosophy and comedy. Aristophanes, Logos and Eros, Bloomington 2008.

Guczalska K., Państwo jako dzieło sztuki. Piękno i wolność w filozofii Hegla, Kraków 2010.

Hamacher W., Das Ende der Kunst mit der Maske, [w:] Sprachen der Ironie - Sprachen des Ernstes, hg. K. H. Bohrer, Frankfurt am Main 2000, s. 121-155.

Hebing N., Hegels Ästhetik des Komischen, Hamburg 2015.

Hegel G. W. F., Fenomenologia ducha, t. 2, przeł. A. Landman, Warszawa 2010.

${ }^{67}$ G. Steiner, The Death of Tragedy, New York 1996, s. 18-19. 
Hegel G. W. F., Wykłady o estetyce, t. 3., przeł. J. Grabowski, A. Landman, Warszawa 1967.

Hegel G. W. F., Wykłady z filozofii dziejów, t. 1, przeł. J. Grabowski, A. Landman Warszawa 1958.

Hegel G. W. F., Wykłady o estetyce, t. 3, przeł. J. Grabowski, A. Landman, Warszawa 1967.

Kraft S., Zum Ende der Komödie. Eine Theoriegeschichte des Happyends, Göttingen 2011.

Marquard O., Schwierigkeiten mit der Geschichtsphilosophie, Frankfurt am Main 1973.

Michalski R., Rozważania wokół koncepcji śmiechu Platona, „Studia z Historii Filozofii”, t. 6, 2015, z. 4, s. 149-174.

Michalski R., Antyczne źródła pojęcia mimesis, „Filo-Sofija”, nr 5, Bydgoszcz 2005, s. $45-64$.

Nussbaum M., Aristophanes and Socrates on Learning Practical Wisdom, „Yale Classical Studies", vol. 26, 1980, s. 43-97.

Plessner H., Śmiech i płacz. Badania nad granicami ludzkiego zachowania, przeł. A. Zwolińska, Z. Nerczuk, Kęty 2004.

O'Regan D., Rhetoric, Comedy and the Violence of Language, Oxford 1992.

Ritter J., Über das Lachen, w: idem, Subjektivität. Sechs Aufsätze, Frankfurt am Main 1974.

Schulte M., „Tragödie im Sittlichen”. Zur Dramentheorie Hegels, München 1992.

Snell B., Odkrycie ducha. Studia o greckich korzeniach europejskiego myślenia, przeł.

A. G. Onsymow, Warszawa 2009.

Steiner G., The Death of Tragedy, New York 1999.

Śmiechowicz O., Arystofanes, Warszawa 2015.

Zupančič A., The Odd One In: on Comedy, London 2007.

Żelazny M., Heglowska filozofia ducha, Toruń 2000.

\section{Abstract \\ Aristophanes' Clouds in the Light of Phenomenology of Spirit. A Contribution to the Anthropological Interpretation of the Phenomenon of Comedy}

The starting point of the article is a reconstruction of Hegel's reflections on comedy contained in the Phenomenology of Spirit. The German philosopher puts forward the thesis that comedy is the culmination of the "religion of art" and exceeds - in terms of the degree of self-knowledge of the spirit and development of freedom - a tragedy. In the second section, I try to show that comedy is a peculiar, 
underestimated foreground of philosophy, from which one can deduce a post-tragic image of man different from the one proposed by the Lacanian school, Rorty's ironism or Sloterdijk's kynism. The point of reference will be Aristophanes' comedy titled "Clouds". While analyzing selected topics of this comedy, I will try to justify the thesis that the fate of Strepsjades, the main comic character, shows the process of his inner transformation. In the finale of the comedy, Aristhopanes presents the subject who freed himself from the pressures of particular needs and abstract principles, and become the medium of the birth of comic Dionysus, in which the vital human potential: "more life" (Nietzsche) or Erros (Bielik-Robson) is freed. The new comic subjectivity opposes the terrorizing power of death, fear and necessity. The finale of the comedy presents the reconciliation of subjectivity, reconciled with itself, in which the untapped, creative potential of speech and action is awakened. These comedy-Dionysian births of man open to him the perspective of a new, concrete natura naturans, grounded in a unique, individual existence, anarchic and rebel, but penetrated by a critical reflection that wants the common good in the name of the joy of life.

Keywords: comedy, Aristophanes, Hegel, freedom, Erros, subjectivity, substance, myth, death, necessity 